\title{
UNGARIS EESTI KEELT ÕPPIVATE ÜLIÕPILASTE KOMMUNIKATIIVNE KOMPETENTS
}

\section{Marju Ilves}

Ülevaade. Kommunikatiivne kompetents on võime keelt tõhusalt ja olukorrale vastavalt kasutada, sisuliselt tähendab see suhtlemisoskust. Kommunikatiivse kompetentsi moodustavad leksikaalne, sotsiolingvistiline/sotsiokultuuriline ja pragmaatiline kompetents. Eesti keele õpetamine välismaal toimub peaasjalikult deskriptiivselt. Ungarlastele mõeldud eesti keele õpik pakub deskriptiivse materjali kõrval lugemispalu ja näitedialooge suhtlussituatsioonide kohta, kommunikatiivsed ülesanded õpikus puuduvad. Kommunikatiivse keeleõppemeetodi kasutamine keeletunnis valmistab keeleõppijat ette teatud tüüpilisteks suhtlussituatsioonideks, millega ta keelekeskkonda sattudes kohe kokku puutub. Koostasin ungarlastest eesti keelt õppinud/õppivatele üliõpilastele mõned lihtsamad suhtlussituatsiooni kirjeldused, milles oli antud suhtluseesmärk ning oli vaja leida keelelised vahendid selle lahendamiseks (nt Kuidas küsid tänaval kella?). Kontrollmaterjalina kasutasin Tartu Ülikooli eestlastest üliõpilaste ja Szombathely Kõrgkooli ungarlastest üliõpilaste vastuseid. Uurimusest selguvad mõned kultuurilised erinevused ja see, kuivõrd on Ungaris eesti keele õppija ette valmistatud autentseteks suhtlussituatsioonideks.

Võtmesõnad: kultuuridevaheline suhtlus, kommunikatiivne keeleõppemeetod, palve strateegiad, viisakusstrateegiad, eesti keel, ungari keel 


\section{Sissejuhatus}

Eesti keelt võõrkeelena õpetatakse välismaal mitmes riigis, ligi neljakümnes kõrgemas õppeasutuses. ${ }^{1}$ Ungaris saab eesti keelt õppida viie ülikooli juures (Budapest, Debrecen, Szombathely, Szeged, Miskolc). Budapesti ülikooli juures on nüüdseks käivitunud eesti filoloogia eriharu; Debreceni, Szombathely ja Szegedi ülikoolis on eesti keel üheks kohustuslikuks aineks soome-ugri eriharu üliõpilastele; Miskolcis ei ole eesti keele õpetus järjepidev, eesti keelt õpetatakse ungari filoloogidele.

Keelekeskkonnast kaugel on keele õpetamisel kitsamad võimalused, samuti sõltub keeleõppe meetodi valik õppijaskonna motivatsioonidest. Eesti keelt õpetatakse välismaal peamiselt deskriptiivselt. Ungarlastele eesti keele õpetamist toetab spetsiaalselt nende jaoks koostatud eesti keele õpik (Kippasto, Nagy 2002). See õpik pakub deskriptiivse materjali kõrval lugemispalu ja näitedialooge suhtlussituatsioonide kohta ("Postimajas”, “Teatris”, "Turul ja poes”), kommunikatiivsed ülesanded õpikus puuduvad. Kuid kuivõrd õppijatel on võimalus sattuda vastavasse keelekeskkonda, tuleks keeletundides käsitleda ka tüüpilisi, korduvaid suhtlussituatsioone.

\section{Kommunikatiivne kompetents}

Kommunikatiivne kompetents tähendab sisuliselt suhtlemisoskust, võimet keelt tõhusalt ja olukorrale vastavalt kasutada. Kommunikatiivse kompetentsi moodustavad keeleline, sotsiolingvistiline/-kultuuriline ja pragmaatiline pädevus. Keelelise pädevuse all mõistame seda, et kasutatakse korrektselt vastava keele grammatilisi reegleid, sõnavara, semantikat, fonoloogiat. Sotsiolingvistiline/-kultuuriline pädevus tähendab seda, et tuntakse suulise kõne ja kirjaliku vormistamise traditsiooni (nt kuidas kõnetada kedagi suuliselt või kirjalikult) ning eristatakse keelelisi olukordi (keelelised vahendid valitakse vastavalt tingimustele). Pragmaatiline pädevus hõlmab suhtluseesmärkide tundmist ja nende kasutamise teadvustamist, samuti keele funktsioonide teadvustamist (nt kuidas paluda, tänada või vastata antud situatsioonis) (Medgyes 1997: 124, Ehala jt 1997: 168).

Osav ja kompetentne vestleja teab omas kultuuris üsna hästi, kuidas vestlust alustada, millest rääkida, millist registrit kasutada. Edukaks toimetulekuks teises kultuuriruumis on vaja kõigepealt tunda iseennast, oma keelt ja kultuuri ning näha erinevusi oma ja teise kultuuri suhtlusmallide vahel (Pajupuu 1997: 547).

Suhtlemisel kasutame suhtlemisstrateegiaid. Võõrkeele õppimisel laename suhtluseks vajalikud mallid oma emakeelest või mõnest muust omandatud keelest ning kui see laenamine osutub tulemuslikuks, st kui tulemkeel aktsepteerib laenatud elemendi, võtab keelekasutaja selle elemendi oma keeltevahelisse repertuaari (Corder 1992: 16). Suhtlussituatsioonide keele funktsioonid on need vajadused ja eesmärgid, mida keele abil on võimalik väljendada või saavutada, näiteks palve, küsimus, küsimusele vastamine, kutse (Ehala jt 1997: 16). Suhtlussituatsioonidel on olemas teatud universaalid, näiteks palve koosneb kõnetamisest (address term), põhitegevusest (head act) ja seonduvatest lisanditest (adjuncts), alati see ülesehitus muidugi nii täiuslik pole. Palve esitamiseks võime kasutada küsilauset, eitavat vormi, käsklauset, konstateerivat lauset, tingivat kõneviisi,

${ }^{1}$ Vt http://www.hm.ee (21.09.2005). 
tingiva kõneviisiga kõrvallauset ja nende kombinatsioone. Leksikaalsete leevendajatena saame kasutada teatud tüüpi sõnu: viisakusvormeleid, aja- ja viisimääruseid, umbisikulisi asesõnu. Nimetatud universaalid ei toimi aga igal pool, näiteks hispaania või jaapani keeles pole võimalik kasutada tingivat konstruktsiooni palvena (Szili 2002).

\section{Uurimus}

\section{Tutvustus, hüpoteesid}

Soovisin välja selgitada, kas eesti keele õppija Ungaris on ette valmistatud autentseteks keelesituatsioonideks Eestis. Eesmärgi saavutamiseks kogusin materjali suhtlussituatsioonide lahendamise kohta nii ungarlastest eesti keele õppijate kui ka eesti keelt emakeelena, samuti ungari keelt emakeelena kõnelevate üliõpilaste käest. Emakeelsetelt kogutud materjali nimetan kontrollmaterjaliks. Ungaris eesti keelt õppivate üliõpilaste käest kogutud lahendite paigutamine kontrollmaterjali taustale aitab jälgida,

1) kas nende kasutatud lahend on kooskõlas emakeelsete eestlaste kasutatud malliga,

2) kas nende kasutatud lahend, mis pole kooskõlas emakeelsete eestlaste kasutatud malliga, on tingitud üliõpilase emakeelele - ungari keelele omasest mallist.

Tahtsin teada, kas Ungaris eesti keelt õppivad üliõpilased kasutavad oma vastustes emakeelele omaseid suhtlemismalle, emakeelele omaseid viisakusnorme. Tundsin huvi ka repliikide pikkuse vastu. Eeldasin, et ungari suhtlemiskeelele omase sõnarohkuse tõttu on emakeelsete eestlaste repliikidest pikemad ka Ungaris eesti keelt õppivate üliõpilaste repliigid. Vaatlesin ka seda, milliseid keelelisi vahendeid kasutati ning mis võis tingida sellise kasutuse. Kokkuvõtvalt oletasin, et suhtlusmalli valikul saavad määravaks kultuurilised ja keelelised erinevused, võimalikud individuaalsed erinevused jätsin kõrvale.

\section{Uurimuse metoodika}

Koostasin mõned lihtsamad suhtlussituatsiooni kirjeldused, kus oli antud suhtluseesmärk ning oli vaja leida keelelised vahendid selle lahendamiseks (nt Kuidas küsid tänaval kella?). Situatsioonide seas oli kolm palvet, kaks informatsioonipäringut, üks kutse ning kaks reageeringut pakkumisele. Situatsioonides erinesid oletatavad partnerid - õpetaja, vanemate sõbrad, oma sõbrad, vanem proua.

Situatsioonid lugesin ette eesti keelt õppinud/õppivatele ungari üliõpilastele ning palusin neilt situatsioonile sobivat keelelist reageeringut (või tegi sama minu hea kolleeg Debrecenis või Budapestis; uurimuse läbiviimise ajal oli eesti keele õpe Szegedis veel algusjärgus ning oletatavasti ei oleks seal sobivaid tudengeid leidunud, Miskolci ülikooli juures pole eesti keele õpe järjepidev). Kõlanud repliigid pani kirja küsitluse läbiviija, nii oli üliõpilastel vähem põhjust muretseda grammatiliste eksimuste pärast. Sissejuhatavas vestluses ka selgitati üliõpilastele, et grammatiline korrektsus pole selles uurimuses esmatähtis. Eeldasin uuringus osalenud üliõpilaste keelelist kompetentsi - osalesid ainult need üliõpilased, 
kes olid eesti keelt õppinud vähemalt poolteist aastat ja kelle sõnavara oli piisav suhtlussituatsioonide lahendamiseks. Üliõpilaste sotsiolingvistilist/-kultuurilist ja pragmaatilist kompetentsi aitab selgitada kontrollrühm. Kontrollmaterjalina kasutasin Tartu Ülikooli eestlastest humanitaarala tudengite ja Szombathely Kõrgkooli ungarlastest humanitaarala tudengite vastuseid. Kontrollmaterjal näitab, kuidas käituks situatsioonis emakeelne kõneleja. Oletasin, et kontrollrühmade kasutamine aitab jälgida ka seda, kuivõrd mõjutavad suhtlemist kultuurilised erinevused: näiteks juhul kui eri kultuurid kasutavad erinevaid suhtlusstrateegiaid, võib võõrkeeleõppija suhtlusmalli laenata oma emakeelest. Kontrollrühmades toimus situatsioonide lahendamine vastavalt ühe eestlasest või ühe ungarlasest kolleegi kaasabil, kes situatsiooni ette luges. Üliõpilased kirjutasid oma repliigid ise paberile.

Vastuseid sain kokku eesti keelt õppivalt 13 ungarlaselt (7 Budapestis, 3 Debrecenis, 3 Szombathelys), kontrollrühmades osales 35 emakeelset ungarlast ja 24 emakeelset eestlast. Andmete vähesuse tõttu ei saa seda uurimust representatiivseks pidada, kuid mõned tendentsid joonistuvad välja. Keskmine vanus sihtgrupis oli 25 aastat, kontrollrühmades pisut madalam: 19-20 aastat. Et tegu oli humanitaarala üliõpilastega, oli märgatav naissooline ülekaal, kuid soolised erinevused olid vastustes marginaalsed ning jäävad käsitlemata.

Edaspidi on näidetes eesti keelt õppinud ungarlaste vastused esitatud kaldkirjas, emakeelsete kontrollrühmade vastused on tavakirjas, emakeelsete ungarlaste vastused on koos eestikeelse tõlkega. Eestikeelsete materjal esitatakse muutmata kujul, ungarikeelsed repliigid on tõlkinud artikli autor. Ungaris eesti keelt õppivate üliõpilaste suusõnalise materjali on kirja pannud emakeelne eestlane, repliikide keelevead on parandamata.

\section{Palve}

Palve on selline ütlus, mille eesmärk on panna kuulaja midagi tegema. Palve funktsioon on sarnane käsu funktsiooniga. Funktsiooni täitmiseks kasutatakse aga erinevaid keelelisi vahendeid, opereeritakse erinevate viisakusstrateegiatega (nt palves kasutatakse leksikaalseid leevendajaid). Eesti keeles võib palve esitada käsklausena, kuid tavaliselt pehmendatakse käsklauset teatud tüüpi sõnade abil, nt palun, ole hea (Pajusalu 2002: 22). Palve võib olla kuulajale orienteeritud, rääkijale orienteeritud, topeltorientatsiooniga või umbisikuline. K. Szili refereerib S. Blum-Kulka jt (1989) esitatud üheksat palve esitamise strateegiat (Szili 2002, näitelaused on artikli autorilt):

1. käskiva kõneviisiga palve / mood derivable - kõige otsesem strateegia, milles palvet märgitakse grammatilise kõneviisiga, nt käskiva kõneviisiga või selle funktsionaalsete vastetega elliptilistes lausetes:

Ärge minge ära! (Esitage) kodused ülesanded!

2. otsene performatiivne palve / explicit performative - kõneleja eesmärk avaldub vastava performatiivse tegusõna palun kasutamises:

Palun arvet!

3. varjatud palve / hedged performative - palvet väljendav tegusõna esineb koos modaalse abitegusõnaga:

Kas ma võiksin sult suitsu küsida? Ma tahaks sinult pliiatsit paluda. 
4. tuletatud palve / locution derivable - palve tuletame kõneaktist:

Kas sa annaksid mulle suitsu?

5. tahteavaldus / want statement - kõneleja avaldab soovi mingi tegevuse toimumiseks:

Tahaksin sinult suitsu. Tahaksin maksta.

6. ettepanek / suggestory formula - diplomaatiline, kuulajale orienteeritud vorm:

Mis oleks, kui teeks ühe suitsu? Äkki soovid kohvi?

7. ettevalmistav palve / preparatory - testib kuulaja suutlikkust mingiks tegevuseks:

Kas Te võiksite arve tuua? Kas sa saaks mind aidata?

8. tugev vihje / strong hint - palvet ei saa lokutiivsest kõneaktist otseselt tuletada, ent oluline vihje palveks on lauses olemas:

On sul teist pastakat? Kas sa lähed linna?

9. kerge vihje / mild hint - isegi kõneaktis puudub oluline vihje palveks, see strateegia eeldab kuulajalt konteksti põhjalikumat tundmist:

Siit on nagu sõda üle käinud. 'Siin on korralagedus, tee see korda!'

Ungaris on levinuimaks 1., 7. ja 3. strateegia, kuid sõpradega suhtlemisel 1. strateegiat ei kasutata. Ka teistes keeltes on sarnased eelistused (Szili 2002).

Minu uurimus näitas, et ungarlased kasutavad palve esitamisel tõepoolest valdavalt 7. ja 3. strateegiat, harvadel juhtudel ka 8. ja 2. Emakeelsete eestlaste vastustes kasutatakse kõige enam 8. vihjestrateegiat, samuti 7. ja 2. strateegiat, vähemal määral on käibel 3. ja 4. strateegia. Eesti keelt õppivad ungari üliõpilased kasutaksid enamasti samuti vihjestrateegiat (8.) ja seejärel ettevalmistavat strateegiat (7.).

Suhtlussituatsioonide seas otsisin lahendeid kolmele palvele. Kaks neist on nn rutiinipalved, milles esineb argine situatsioon ning palve moodustamine peaks igapäevase sõnavara abil kiiresti toimuma. Rutiinipalve täitmine eeldab partnerilt ainult üht lisaliigutust, tavaliselt ei lükata rutiinipalvet ka tagasi. Ühes situatsioonis tuli küsida sõbralt suitsu: Tahad suitsetada, aga Sul ei ole suitsu. Küsid sõbralt. Teises situatsioonis paluti loengunaabrilt pastakat, situatsiooni kirjeldus kõlas nii: Oled loengus ja Sul pole pastapliiatsit. Küsi naabrilt! Suitsuküsimise situatsiooni lahendamine ei nõudnud pikka mõtlemisaega (nõutust tekkis siis, kui üliõpilane oli mittesuitsetaja, sel juhul ei tohiks suitsu palumist ka rutiinipalveks pidada).

Emakeelsete ungarlaste vastuste põhjal oleksid ootuspärased pikad ja mitmekülgse leksikaga palve vormistused, nt van egy szál cigid kölcsönbe? 'kas sul on üks suits laenuks?' holnap “visszahívlak” 'homme teen mina sulle välja', szeretnék rágyújtani 'paneks suitsu ette', visszaadom holnap 'homme annan tagasi', nem gáz? 'kui pole hullu?' jne. Eesti keelt õppivate ungarlaste enamik kasutas sarnaselt emakeelsete eestlastega siiski just lühikest ja tuletatud malli:

Kas sul on suitsu?

Kõnetamiseks kasutasid eesti keelt õppivad ungarlased lause alguses viisakusvorme Vabandust!, Palun vabandust!, mida eestlased sõprade vahel reeglina ei kasuta. Sarnase viisaka pöördumise leiame aga ungari kontrollrühma vastustest: ne haragudj, bocs, bocsi ‘ära pahanda, vabandust'. Kõnetamisel kasutavad eesti 
üliõpilased pooltel juhtudel kuule-vormi, ungari keeles on analoog samuti esindatud: Te figyu, figyi! Kui emakeelsete eestlaste kontrollrühm püüab siin tähelepanu ainult vormiga kuule, siis ungari kontrollrühmas on lisaks vabandusele ja kuule-vormile veel võimalikud nimeline pöördumine, tervitus või hellitav pöördumine (drágám 'kallis'). Kontrollrühmad tähelepanu köitmiseks vandesõna ei kasuta, küll aga vormistab üks eesti keelt õppinud mittesuitsetajast tüdruk oma palve järgmiselt:

Kurat! Mul pole suitsu, kas sa saaks mulle anda?

Eesti keelt õppivate ungarlaste pöördumiseta lahendid pole kohatud, sest nii eesti kui ungari kontrollrühma materjalis leidub väljendeid, mis kohe palvet väljendavad.

Tänamine repliigi lõpus on emakeelsete eestlaste andmete põhjal sellises interaktsioonis tundmatu, ent ka ungari kontrollrühmas esineb see vaid ühel juhul. Samuti ei kasuta emakeelsed eestlased palun-vormi. Emakeelsete eestlaste vastustes esinenud kõnekeelseid vorme

Loobi mind ühe sigaretiga!

Viska üks!

Teeks kimu!

eesti keele õppijad ei kasuta. Et suitsu küsimine on rutiinipalve ja selle moodustamine toimub kiirelt ja lakooniliselt, kõlavad eesti keele õppijate pika sissejuhatusega palved võõrana:

Kas sa tahad minuga suitsetada? Sest ma tahaksin, aga mul ei ole suitsu.

Palun vabandust, kas sul on sigaretid siin?

Ma tahaksin suitsetada ja kas sa saaksid mulle anda mõned sigaretid?

Pastaka küsimisel ei sega eesti keele õppijate suhtlussituatsioonide lahendeid ungari mall, mis algab valdavalt mõne vabandava pöördumisega: bocsi, bocsika, ne haragudj, légyszíves 'vabandust, ära pahanda, ole kena'. Mõnes üksikus vastuses näeme palun-vormi kasutust. See langeb kokku emakeelsete eestlaste vastustega, milles esineb üliharva vabandust ja palun. Võrdluseks kõrvutaksin emakeelsete eestlaste levinud malli:

Laena mulle palun pastakat!

ning eesti keele õppijate poolt kasutatud malli:

Palun, kas sa võiksid mulle teist pliiatsit anda?

Nii eestlaste kui ka eesti keelt võõrkeelena õppijate palvetele on iseloomulik, et pastakat palutakse määratud ajaks ja palve vormistatakse enamasti küsimusena:

Kas sul on teine /veel üks/vaba pliiats?

Palvele lisab põhjenduse üks küsitletud eesti keelt õppivast ungarlasest:

Mul ei ole pastakat. Kas sul on mulle üks?

Emakeelsete kontrollrühmas põhjendust nii lihtsalt ei konstateerita, oma palvet vabandatakse pastaka koju unustamise või kaotamisega.

Eesti keele õppijad kasutavad palve esitamisel abiverbe saama, tahtma, võima. Emakeelsete eestlaste kontrollrühm kasutab ainult verbi saama.

Kui rutiinipalvete esitamise juures ei esinenud suuri erinevusi eestlaste ja eesti keelt võõrkeelena õppivate üliõpilaste vahel, siis mitteigapäevase palve juu- 
res muutusid erinevused märgatavaks. Nimelt esines suhtlussituatsioonide seas selline, kus külas olles tuli pererahvalt paluda luba arvuti kasutamiseks elektronposti vaatamiseks: Oled oma vanematega nende sõprade pool külas. Perepoeg Pauli pole kodus. Sa oled seal esimest korda külas ja tahaksid teada, kas võid Pauli arvutit kasutada, et oma e-meili vaadata. Su vanemad vestlevad Pauli vanematega. Kuidas Sa küsid, kas võid arvutit kasutada? Erinevus rutiinipalvest peitub ka selles, et siin palutakse luba kalli asja kasutamiseks, liiatigi ei paluta seda oma sõbralt ega healt tuttavalt, vaid oma vanemate tuttavatelt, kellega kohtutakse esmakordselt. Mitteigapäevase palve moodustamine on aeganõudvam ning nõuab rohkem improviseerimisoskust. Eeldatavasti ei lahendata olukorda sarnaselt rutiinipalvega.

Selle ülesande puhul oli hämmastav ungarlaste kontrollrühma ebalevus situatsiooni suhtes: kord ühes emakeelsete ungarlaste rühmas küsimustikku läbi viies ütles kohalviibinud kuuest tudengist neli, et nad ei tahakski niiviisi arvutit kasutada. Selline tõrge võib olla põhjendatav ühiskondlike erinevustega - Eestis on arvuti igapäevasem ja selle kasutamine vabam. Emakeelsete eestlaste kontrollrühmas andsid situatsioonile lahendi kõik üliõpilased. Eesti keelt õppivad ungarlased loobusid vastuse andmisest kolmel korral.

Sarnaselt suitsu küsimisega alustasid eesti keele õppijad ka seda palvet valdavalt vabandamisega. Levinumad on need mallid, kus eesti keele õppija küsib arvuti kasutamiseks lihtsalt luba, jättes lisamata selle, mis eesmärgil, ajendil või kui kauaks soovitakse kallist tehnikat oma meelevalda saada:

\section{Vabandust, kas ma võiksin Pauli arvutit kasutada?}

Tean, et Paul ei ole kodus, aga kas te arvate, et ma saan tema arvuti kasutada?

Paaril korral küsitakse arvuti kasutamise luba natukeseks ajaks. Paaril korral rõhutatakse, et kasutamine on seotud tähtsa asjaga:

Vabandust. Mul on tähtis asi. Ma tean, et Pauli toas on arvuti, kas ma võin seda kasutada.

Vabandust, mul oleks üks küsimus. Mis te arvate, kas Paul oleks väga vihane, kui ma tema arvutit kasutaks, sest mul oleks väga vaja meili tšekkida?

Eelmine on ka ainus näide arvuti kasutamise eesmärgi kohta (elektronposti vaatamiseks).

Kontrollrühmi võrreldes selgub siin, et ungarlased küsiksid luba pikemalt kui eelmistes rutiinipalve situatsioonides ning ka pikemalt kui eestlased: ungarlased vabandaksid alguses vestlusse vahelesegamise pärast, siis juhatatakse sisse palve (lehetne egy kérésem 'mul oleks üks palve', csak azt szeretném kérdezni 'ma tahaksin ainult küsida') ning viimaks põhjendatakse arvuti kasutamise eesmärki (megnézzem az email-jeimet 'vaataksin meili'). Paaril juhul pöördutakse otse kellegi poole (nt Angie-néni 'tädi Angie'), ent ühel juhul ollakse vägagi üldine: $M e g$ tudom nézni valahol az emailjeimet? 'Kas ma saaksin kuskil oma meili vaadata?'.

Emakeelsete ungarlaste kontrollrühmas esines ka üks hea näide selle kohta, kuidas ebahariliku palve elava improvisatsiooni abil saab moodustada. Kõigepealt sulatakse oma repliigiga vestlusesse ning palveni jõutakse sujuvalt vestluse käigus: 
Tényleg? Igazatok van, akkor én is ott voltam, meg a Kati is. Tényleg a Kati! Teljesen elfelejtettem! Meg kellett volna néznem a nekem küldött email-jét! Elnézést, önöknek nincs véletlenül internetük, használhatnám egy kicsit? (Tõesti? Teil on õigus, ma olin ju ka siis seal ja Kati oli ka. Tõepoolest Kati! Mul läks täiesti meelest ära! Ma pidin ju meili vaatama, mis ta mulle saatis. Vabandust, ega Teil ei ole juhuslikult internetti, kas ma võiksin seda natuke kasutada?)

Viisakusreeglite järgi peaks mitte väga tuttavaid vanemaid inimesi teietama (situatsioonis on tegu oma vanemate sõpradega), emakeelsete ungarlaste kontrollrühmas paaril juhul siiski ka sinatati:

Ne haragudjatok, hogy megzavarlak titeket, de lenne egy nagy kérésem. Mivel otthon nincs számítógépem, megnézhetném az e-mailjeimet Paul gépén? Köszönöm! (Vabandust, et ma teid segan, aga mul oleks üks suur palve. Kuna mul kodus ei ole arvutit, siis kas ma võiksin Pauli arvutis oma meili vaadata? Aitäh!)

Nii nagu suitsu palumisel, pakuvad emakeelsed ungarlased ka siin võimalikku vastuteenet:

Nem szeretném megzavarni a beszélgetést, és tolakodónak sem szeretnék tünni, de használhatnám Paul számítógépét, hogy megnézhessem a mailjeimet? Természetesen, amikor jövő hétvégén tetszenek jönni hozzánk, Paul is használhatja majd az enyémet! (Ma ei tahaks vestlust segada ega pealetükkivana näida, aga kas ma võiksin Pauli arvutit kasutada, et oma meili vaadata? Loomulikult, kui Te järgmisel nädalavahetusel meile tulete, võib Paul minu arvutit ka kasutada!)

Ühel juhul rõhutatakse seda, et arvutit ei kahjustata:

Elnézést kérek a zavarásért, csak meg szerteném kérdezni, hogy a fiúk nagyon haragudna-e azért, ha egy pillanatra használnám a számítógépét. Nem tartana sokáig és vigyaznék a gépre. (Palun vabandust, et ma vahele segan, aga ma tahaks ainult küsida, kas Teie poeg oleks väga pahane, kui ma korraks tema arvutit kasutaksin. See ei võtaks palju aega ja ma oleksin arvutiga ettevaatlik.)

Ka eestlaste kontrollrühm esitab selle palve pikemalt kui rutiinipalve, kuid tunduvalt lühemalt kui ungari kontrollrühm. Palves lasub rõhk pigem arvuti kasutamise lühiaegsusel, mitte kasutamise tähtsusel. Otse kellegi poole ei pöörduta, kodust arvuti puudumist ei tooda ettekäändeks, samuti ei nähta arvuti kasutamises võimalikku probleemi (ungari keeles lõpetati palve vahel nii: remélem nem gond 'loodan, et see pole probleem', ha nem nagy gond 'kui see tüli ei tee', ha csak nem lesz ebből probléma 'kui sellest muidugi probleemi pole') ega lubata vastuteenet.

\section{Infopäring}

Esitatud suhtlussituatsioonide seas esines kaks infopäringut. Ühel juhul tuli tänaval vastutulijalt kella küsida, teisel juhul liftis kaassõitjalt küsida, mitmendale korrusele ta sõita soovib. 
Kella küsimisel kasutavad eesti keelt õppivad ungarlased kohustuslikult lauseosa mis kell on?, variatsioone sellele pole (vrd emakeelena kõnelejate palju kell on, saate kella/kellaaega öelda). Et situatsiooni kirjeldus kõlas kujul: Oled tänaval ja küsid vastutulijalt kella, ei ole selline infopäringu formeering otsesest kirjeldusest tuletatud automaatne vastus. Eelistatult kasutatakse isikuta pöördumist:

Vabandust, mis kell on?

Isikuta vormi kasutust võib põhjustada see, et püütakse vältida otsustamist sinateie vahel. Teietamise puhul raskendab lause moodustamist see, et eesti ja ungari keel kasutavad teietamiseks erinevaid isikuid: eesti keel mitmuse teist ja ungari keel sõltuvalt teietatavate isikute arvust ainsuse või mitmuse kolmandat.

Kella küsimisel kasutatakse tavaliselt malli, mis viitab kõnetatu suutelisusele (oskate, võite, saate). Lisaks kasutavad vastanud emakeelsed eestlased verbivormi teate:

Vabandage, kas teate, mis kell on?

Raskus ungarlasest eesti keele õppijale on see, et nendele neljale verbile vastab ungari keeles üks verb (tud 'oskama') ning keeleõppija ei pruugi eesti verbide tähendusnüansse tunnetada. Seega on ootuspärane, et eesti keelt õppivate ungarlaste verbikasutuse ampluaa on siin kitsam. Ei kasutata vormi oskate, mis oli levinuim eestlaste kontrollrühmas, abitegusõnadest varieeritakse vaid verbiga saama ja võima. Eestlaste kontrollrühmas esineb saama ja võima igal juhul tingivas kõneviisis, eesti keelt õppivate ungarlaste kõnes kohtame ka kindlat kõneviisi:

Vabandust, kas sa saad mind öelda, mis kell on?

Tere! Vabandust, kas te võite öelda, mis kell on?

Üks eesti keelt õppiv ungarlane kasutab infopäringus kohatuna mõjuvat tahtma verbi:

Vabandust, kas te tahaksite mulle öelda, mis kell on?

Kohatu ja liiga semulik on ka infopäring kujul:

Kas sa tead, räägi mulle, mis kell on.

Eelnenud kaks ütlust ei ole ungari keelest laenatud kompensatsioonistrateegiad.

Lifti situatsiooni kirjeldati üliõpilasele nii: Sisened lifti, kus on enne Sind juba üks vanem proua. Tahad teada, mitmendale korrusele tema sõidab. Mis sa ütled? Korrusesoovi küsimisel on eesti keelt õppivad ungarlased oma vastustes hästi tabanud eestlastele omast lakoonilisust:

Mitmes korrus?

Mis korrus?,

ehkki emakeelsete eestlaste vastustes esineb veelgi lühemaid, ühesõnalisi variante:

Mitmendale?

Mitmes?

(Üks eestlasest üliõpilane ütleks enda korruse numbri küsiva intonatsiooniga ja jääks ootama vastust: Kolmas?)

Ungari keeles lahendatakse vastav suhtlussituatsioon pikema repliigiga. Jälgi ungari keele mallist leiame järgmisest eesti keele õppija lausest:

Ma sõidan kolmandale korrusele. Mitmendale korrusele sõidate Te? 
Huvitav on see, et eesti keele õppijad selles situatsioonis isikulise vormi valimisel sina-teie kasutamisega ei eksi. Võibolla on siin abistavaks teguriks see, et situatsiooni kirjeldus esitab liftikaaslaseks ühe vanema proua.

Eestis lifti sisenemisel võõraid ei tervitata, ungari käitumisharjumuste mõjul lipsab see "kohatu viisakus" eesti keelt õppivate ungarlaste repliiki paaril juhul sisse:

Tere, vabandust, mitmendale korrusele Teie sõidate?

Kompensatsiooniline laen ungari keelest on ka:

Vabandust. Missugusele korrusele tahaksite minna? (vrd tetszik menni, szeretne menni)

Liftisituatsiooni lahendiks pakkusid eesti keelt õppivad ungarlased ka mõne liiga otsese või uudishimutsevalt konkreetse lahendi kujul:

Mis nuppu ma vajutan?

Kuhu Te lähete?

Sarnast otsest ja enesele orienteeritud malli ei kasuta minu uuringus ükski eesti ega ungari keele emakeelne kõneleja.

\section{Vastus pakkumisele}

Igapäevases suhtluses esineb tihti olukordi, kus meie palvet ennetatakse omapoolse pakkumisega. Analüüsisin kahte igapäevast situatsiooni, milles tuli pakkumisele reageerida. Ühel juhul pakuti lisa lõunalauas, teises telefonitsi teate jätmist sõbrale, keda parajasti kodus pole. Pakkujaks oli mõlemal juhul sarnane isik, ühe sõbra ema.

Situatsioon lõunalauas oli esitatud järgmiselt: Oled sõbra vanemate juures lõunal ja sõbra ema küsib, kas soovid veel midagi. Mida Sa ütled?

Kontrollrühmades võtaks lõunalauas lisa pakkumise vastu neljandik küsitletud eestlastest ja kuuendik küsitletud ungarlastest. Küsitletud eesti keelt õppivatest ungarlastest lükkaksid pakkumise tagasi kõik. Sellise strateegia kasutamise põhjuseks võib olla nii tõekspidamine, et esimene pakkumine on viisakas tagasi lükata, kui ka lihtsam ja lühem viis suhtlus lõpetada. Kui kultuure veel võrrelda, siis ungarlased sooviksid lisana klaasi vett või ôlut või üht koogitükki, eestlased oleksid küsimises julgemad ja humoorikamad: uuriksid, mida veel pakkuda on, või küsiksid sinki, vorsti ja rulaadi...

Obligatoorne Aitäh! on eesti keelt õppivate ungarlaste vastustes olemas, v.a üks erand:

Ei taha enam, mul on kõht täiesti täis.

Ent ühe sarnase näite leiame ka emakeelsete eestlaste kontrollrühmast:

Ei ole vaja, mul on juba kõht täis.

Lisast loobumist põhjendavad eesti keele õppijad kõhu täis olemisega:

Aitäh, aga ei, mul on kõht täis.

Aitäh, ei, mina olen täis!

Paaril juhul on see põhjendus kombineeritud toidu kiitmisega: 
Kiitmise ja põhjenduse kombinatsioon on kõige levinum mall emakeelsete ungarlaste kontrollrühmas.

Nem kérek semmit, köszönöm. Nagyon finom volt minden és már teljesen jóllaktam. (Ma ei taha midagi, aitäh. Kõik oli väga maitsev ja mul on kõht täis.)

Nem, köszönöm szépen. Elég volt. Finom volt minden. (Ei, suur tänu. See oli piisav. Kõik oli maitsev.)

Toidu kiitmisel on eestlased tunduvalt tagasihoidlikumad kui ungarlased ning eesti keelt õppivate ungarlaste vastustes peegeldub justkui eestlaste lauakommete omandamine: toidu kiitmisega ollakse napisõnalisemad kui Ungaris harjutud.

Telefonivestluses ei soovi eesti keelt õppivad ungarlased valdavalt teadet jätta (seitse ei jäta, viis jätab). Kindlasti on siin tegu jälle sellega, et teate jätmisest loobumine on keeleliselt lihtsam ning telefoniga rääkimine on võõrkeeles üldse komplitseeritum kui silmast silma suhtlemine. Suhtlussituatsioonis mainiti helistamise ajendina sõbraga kohtumise vajalikkust: Helistad sõbrale, et temaga võimalikult kïresti kokku saada. Telefoni võtab sõbra ema, kes ütleb, et Su sõpra pole kodus, ja küsib, kas ta saab midagi edasi öelda. Mida Sina ütled? Teate mittejätmisega libisetakse asja pakilisusest üle. Kontrollrühmades seevastu on ülekaalus teate jätmine (Eestis 19:5, Ungaris 27:8).

Vastuse lühidusega ületavad siin eesti keelt õppivad ungarlased isegi napisõnalisi eestlasi. Kui emakeelsetel eestlastel on kõige lakoonilisemaks vastuseks

Ei ole vaja. Suur tänu!

ja emakeelsetel ungarlastel

Nem, majd felhívom később. (Ei, ma helistan siis pärast.), siis eesti keelt õppivad ungarlased vastavad veelgi lühemalt:

Ei, aitäh!

Helistan uuesti!

Ma helistan jälle!

Paaril korral otsivad teate jätmisest loobunud eesti keelt õppivad ungarlased siiski ka suhtlust alalhoidvaid alternatiive:

Siis ma helistan temale hiljem... Või mis on tema mobiili number?

Kas te räägite, millal ta on kodus?

Pöördumise valikul oleks oodatud teietamine (mida teeb eranditult ungarlastest kontrollrühm), ent vastunäite sellele leiame emakeelsete eestlaste kontrollrühmast:

Tsau, kas sa saaksid X-le edasi öelda, et ta mulle võimalikult kähku tagasi helistaks! Juta olen.

Nii ei saa sinatamist otseselt vääraks pidada ka eesti keelt õppiva ungarlase repliigis:

Palun ütle temale, et ma tahaksin teda näha, ja kui ta saab koju, ta helistaks mulle kohe! 
Eelnevas emakeelse eestlase repliigi lõpus näeme enesetutvustamist (Juta olen.), sama malli leiame ka ühe eesti keelt õppiva ungarlase repliigist, kuid siis paikneb see repliigi algul:

Ma olen Nóri ja ma tahaksin ruttu temaga vestlema. See on väga tähtis.

\section{Kutse}

Igapäevases suhtluses esineb tihti kutset, näiteks kutsutakse meid sööma, telefonile või külla. Üliõpilastel palusin sõnastada kutse, millega küsitlust läbiviiv õppejõud kinno kutsutakse (Tahad mind õhtul kinno kutsuda, kuidas Sa seda mulle ütled?). Sellise kutsesituatsiooni puhul ei ole usaldatavad ja abistavad kontrollrühmade andmed. Kutse esitatakse tavaliselt isikuliselt, seega tuleb taas valida sinatamise ja teietamise vahel. Valik sõltub sellest, missugune võimu- või solidaarsussuhe on üliõpilase ja õppejõu vahel. Ungari kontrollrühmas teietasid üliõpilased oma õpetajat ning veelgi enam: privaatselt õpetaja kinno kutsumist esines vähe, eelistatavalt kutsutaks õpetaja kinno rühmaga või sõpradega minnes, lisaks rõhutatakse kutses seda, et tegu on hea filmiga, väärtfilmiga või kasuliku keeleteadusliku filmiga, mida saaks hiljem seminaris käsitleda. Emakeelsete eestlaste kontrollrühmas üliõpilased nii sinatavad kui teietavad õppejõudu, sõltuvalt personaalsest distantsist esineb nii väga vaba suhtlemist:

Kuuledsa. Selline lugu. Mõtlesin sind täna kinno kutsuda. Mis arvad?

kui ka distantsiga pöördumist:

Vabandage, selline küsimus - ega Te kinno ei tahaks minna?

Hoolimata sellest, et Eesti kinopileti hinnad on ühed kõrgemad Euroopas, ollakse Tartus valmis õppejõule piletki välja tegema:

Kas ôhtul kinno tahad tulla? Hea film on, teen välja.

Eesti keelt õppivad ungari üliõpilased sinatavad oma eesti keele õpetajat. Kutse vormistamisel võõrastust ei tekkinud, pigem oli selle kutse moodustamine lõbus ülesanne, väljakutse. Kui ungari kontrollrühm pöördub õpetaja poole teda õpetajana (Tanárnő!) kõnetades, siis eesti keele õpetajat kõnetavad õpilased solidaarsemalt, kõnetavad nimeliselt:

Lea, kas sul on aega kinno minna?

Lea, kas sa tahaksid õhtul kinno minna?

Kuule, Marju, kas sulle meeldiks õhtul kinno tulla?

Kallis Marju-tädi, kas sa oled vaba õhtul? Ma tahaksin sind kinno minna.

Eesti keelt õppivad ungarlased ei kõnele kordagi filmi iseloomust. Partnerilt küsitakse sissejuhatavalt: kas ta on ôhtul vaba, kas tal on aega. Eesti keele õppijad vormistavad kutse üldiselt, tingivas kõneviisis (näiteid igale mallile leiame ka emakeelsete eestlaste kontrollrühmas):

Kas sa oled vaba täna õhtul? Sest oleks hea minna kinno.

(Emakeelsete eestlaste kontrollrühmas: Läheks kinno, mis sa arvad?)

Eesti keele õppijad oskavad kutse vormistada ka topeltorientatsiooniga malli kasutades, ühist tegevust rõhutades: 
Kas sul on täna õhtul vaba aega? Lähme kinno!

On sul ôhtul aeg? Lähme kinosse!

(Emakeelsete eestlaste mallid: Mis sa õhtul teed? Mis õhtul plaanis? Võik-

sime ehk koos kinno minna!)

Veelgi sagedasemaks kutse esitamise viisiks on mall, milles lähtutakse kutsutust, s.o kuulajale orienteeritud viis (see mall on levinuim ka eesti kontrollrühmas):

Kuule, Marju, kas sulle meeldiks õhtul kinno tulla?

Lea, kas sa tahaksid õhtul kinno minna?

Kutses võib kuulajale orienteeritud malli kombineerida ka enda tahtega:

Kas sa tahaksid õhtul kinno minna? Ma tahaksin sinuga.

Tere! Ma lähen õhtul kinno ja ma tahaksin, et sina tuleksid minuga koos.

Kas sa sooviksid tulla?

Kutse esitamisel kasutatakse nii tingivat, kindlat kui ka käskivat kõneviisi. Käskiva kõneviisi kasutust kontrollrühmast ei leia, aga ka see võib olla seotud erineva solidaarsussuhtega.

\section{Kokkuvõte}

Uurimus püüdis universaalsete suhtlussituatsioonidele lahendeid otsides selgitada, kas Ungaris eesti keelt õppiv üliõpilane on ette valmistatud autentseks keelekasutussituatsiooniks Eestis. Eelnev analüüs vaatles suhtlussituatsioone eraldi, kokkuvõttes toon lühidalt välja jooned, mis on kooskõlas eesti keeles kasutatud mallidega. Kooskõla puudumisel otsin mõjutusi emakeelsest ungari mallist.

Rutiinipalve situatsiooni lahendamisel on eesti keele õppijate repliigid palvestrateegia valiku osas kooskõlas emakeelsete eestlaste omadega. Ungarikeelse malli mõjul esineb neil aga kõnetamises rohkem viisakusvormeleid ning palve pikemat sissejuhatust. Emakeelsetele eestlastele on rutiinipalve esitamisel tähelepanu köitmiseks seevastu iseloomulik kuule-vorm. Palve esitamisel küsivad eesti keele õppijad laenatava asja kasutamiseks lihtsalt luba, ja kui nad siiski otsustavad midagi rõhutada, siis eseme kasutamise lühiaegsust ning vajalikkust (nt küsivad midagi korraks, sest asi on tähtis). Emakeelsed eestlased ei rõhuta enamasti kumbagi, kui kasutamise põhjendamiseks siiski midagi välja tuuakse, siis kasutusaja lühidust. Emakeelsed ungarlased väljendavad palvet kõige pikemalt ning toovad välja eseme laenamise eesmärgi ja tähtsuse.

Kella küsimisel erinevad eesti keele õppijate vastused emakeelsete omadest selle poolest, et loobutakse sina-teie valikust ning kasutatakse ainult isikuta pöördumist. Selle suhtlussituatsiooni lahendamisel on eesti keele õppijate universaalseks keeleliseks vahendiks lauseosa mis kell on? kasutamine. Emakeelsed eestlased kasutavad kella küsimisel mitut verbi, sh verbe saama ja võima ainult tingivas kõneviisis. Eesti keele õppijad kasutavad abiverbidest ainult nimetatud kahte, sh nii tingivas kui ka kindlas kõneviisis. Emakeelsetel ungarlastel esineb valdavalt abitegusõna tud 'oskama' tingivas kõneviisis kombinatsioonis verbi 'ütlema' infinitiiviga (meg tudná mondani).

Kõige suuremad erinevused rühmade vahel esinevad teises infopäringus, liftisituatsioonis. Emakeelsete eestlaste repliigid on lakoonilised, leidub isegi ühe- 
sõnalist päringut. Emakeelsete ungarlaste repliigid on pikad ning algavad tavaliselt viisaka pöördumise või tervitusega. Eesti keele õppijate repliikide seas leiame vasteid mõlema emakeelse rühma mallile, st esineb nii lakoonilisi repliike kui ka pika sissejuhatusega päringuid, mis eesti keeles antud juhul kohatult mõjuvad. Samuti leiame liiga otseseid malle, mis ei ole kooskõlas kummagi kontrollrühma väljenditega.

Situatsioonis, milles tuli vastata pakkumisele, eelistavad eesti keele õppijad pakutavast loobumist. Emakeelsetele rühmade vastuste seas ei ole loobuv reaktsioon nii sage. Eesti keele õppijate loobumise vormistused on isegi lühemad kui muidu lakoonilisematel eestlastel. Kui eesti keele õppijad kasutavad toidulisast loobumisel aga siiski pikemat malli, kombineerivad nad selles loobumise põhjendamise toidu kiitmisega. Sarnase malli leiame ka emakeelsete ungarlaste repliikide seast. Kogutud materjali põhjal ei ole toidu kiitmine emakeelsete eestlaste jaoks levinud mall.

Kutse moodustamiseks saadud keeleline materjal ei sobi kõrvutamiseks. Situatsiooni interpreteerimise taustaks on olnud erinevad võimu- või solidaarsussuhted, isiklikud suhted õppejõuga. Nii kõnetavad eesti keele õppijad õpetajat isikliku pöördumisega (partneri nime abil), emakeelsed ungarlased aga üldisema pöördumisega Õpetaja! (Tanárnő!).

Kokkuvõttes näitavad selle väiksemahulise uurimuse tulemused, et eesti keeles aktsepteeritavad suhtlemismallid on võimalik omandada ka siis, kui autentseks keelekeskkonnaks on õpetaja üksinda. Kommunikatiivset kompetentsi on teatavate kitsendustega võimalik saavutada ka keelekeskkonnast eemal viibides. Suhtlussituatsioonide kasutamises kasutavad eesti keele õppijad lihtsaid konstruktsioone, keerulisemad konstruktsioonid (kus näiteks palves oleksid koos nii tingiv kõneviisi kui ka eitus: Ega sa ei tahaks mulle pliiatsit laenata?) nende kõnes puuduvad. Kuid võõrkeeleõppija keelelised vahendid on ikka piiratumad kui emakeelse kõneleja omad.

Kontrollrühmade kõrvutamisega ja mõjutuste otsimisega ilmnesid kahe kultuuri vahel mõned erinevused ka kõnekultuuris. Kontrollrühmade taustal nägime, et ungari keele suhtlusstrateegiate eeskujul kasutab ungarlasest eesti keele õppija oma eestikeelsetes ütlustes enam viisakusväljendeid kui eesti keeles tavaks. Kuid vahel võib mõnele välismaalase kõnes esinevale võõramale repliigile (nt kus puudub üldine viisakusvormel või sinatatakse teietamise asemel) leida vaste ka emakeelsete kõnes, seega ei saa sellist kasutust täiesti kohatuks pidada. Ent emakeeles levinud mall ei mõjuta alati võõrkeeles kasutatud malli valikut: näiteks on eesti keele õppijate repliigid lühemad kui ungari keeles ning mõnel juhul näib, nagu oleks hästi tabatud eestlastele omast lakoonilist kõnepruuki. Samas võib sellise malli valiku põhjuseks olla lihtne asjaolu, et võõrkeeles, kus end veel väga vabalt ei tunta, väljendutaksegi võimalikult lühidalt.

Sihtkeeles mitteaktsepteeritavate suhtlemismallide kasutust ei saa alati põhjendada emakeeles levinud mallide kasutusega. Võõrkeeles omandatud keelelistest vahenditest tuleb moodustada "õlekõrs", mis viiks suhtluseesmärgi saavutamisele, grammatilised vead on suhtluseesmärgi saavutamisel teisejärgulised. L. Keevallik esitab selle mõtte täpselt ja lihtsalt: 
Ühiskondlikud reeglid ei ole nagu õigekirjareeglid, mis annavad täpseid juhiseid igaks elujuhtumiks, vaid on abstraktsioonid, mida inimesed loovalt kasutavad. Reeglid ei kasuta inimesi, inimesed kasutavad reegleid. (Keevallik 1998: 541)

\section{Kirjandus}

Corder, S. Pit 1992. Strategies of communication. - Strategies in Interlanguage Communication. Ed. by Claus Faerch, Gabriele Kasper. London, New York: Longman, 15-19.

Ehala, Martin; Saarso, Kristi; Vare, Silvi; Õispuu, Jaan 1997. Eesti keele suhtluslävi. Kaasaegsed keeled. Council of Europe.

Keevallik, Leelo 1998. Sinatamisest ja teietamisest koolilaste arvamuste põhjal. Keel ja Kirjandus 8, 541-553.

Kippasto, Anu; Nagy, Judit 2002. Észt nyelvkönyv. (2. trükk.) Miskolc: Bíbor.

Medgyes, Péter 1997. A nyelvtanár. A nyelvtanítás módszertana. Budapest: Corvina.

Pajupuu, Hille 1997. Eestlased ja soomlased - probleemitud suhtlejad. - Keel ja Kirjandus $8,547-550$.

Pajusalu Renate 2002. Lingvistiline pragmaatika ehk Mida kõike inimene oma keelega teha võib. - Oma Keel 2, 21-26.

Szili, Katalin 2002. A kérés pragmatikája a magyar nyelvben. - Magyar Nyelvőr 126/1. http://www.c3.hu/ nyelvor/period/1261/126104.htm (27.09.2005).

\section{Kaudviide}

Blum-Kulka, Shoshana; House, Juliane; Kasper, Gabriele (eds.) 1989. Cross-cultural Pragmatics: Requests and Apologies, Norwood, New Jersey: Ablex. 


\section{COMMUNICATIVE COMPETENCE OF HUNGARIAN LEARNERS OF ESTONIAN AS A FOREIGN LANGUAGE}

\section{Marju Ilves}

Communicative competence is the ability to use the language efficiently and appropriately to the situation, in short it means the ability to communicate. In the wider context the communicative competence is made up by the lexical, sociolinguistic/-cultural and pragmatic competence.

The teaching of Estonian as a foreign language is based traditionally on the grammar-translation method. The only textbook of Estonian for the Hungarian learners makes extensive use of descriptive grammar materials and reading tasks, while communicative tasks are hardly represented at all.

The paper argues that since a great deal of the communicative situations are typical and recurrent, the application of the communicative approach can be of a great value particularly if the language learner has the prospect of using the foreign language in its natural environment.

The present paper draws on a small-scale research based on a test. The test consists of the description of several communicative situations (e.g. How do you ask for the time in the street?) which aimed to find out how students with three different linguistic backgrounds come up with their linguistic realisation. The investigation involved three groups of students: native speakers of Estonian (students of the University of Tartu), native speakers of Hungarian (students of Berzsenyi College Szombathely) and Hungarian learners of Estonian (at Berzsenyi College Szombathely, the University of Budapest, the University of Debrecen). The native speakers of both languages functioned as control groups.

In the results it was remarkable that Hungarian learners of Estonian do not use sophisticated constructions (e.g. do not choose request expressions which involve the use of the conditional tense and negotiation c.f. Ega sa ei laenaks mulle pliiatsit? / Wouldn't you lend me a pen?) but rather opt for simpler expressions than they do in their mother tongue. Comparing the native text production of the two control groups in order to reveal possible interferences from the mother tongue in their use of the foreign language, differences of the two cultures came to light. In accordance with their native communicative strategies, Hungarian learners of Estonian use more polite forms than do Estonian native speakers. In their replies however, they appear to have acquired the Estonian laconic style.

It is a common place that the vocabulary of the foreign language is poorer than that of the mother tongue but this is not an impediment in achieving the communicative goal. The research showed that the acquisition of communicative strategies is possible even in the foreign environment. Social rules are not like orthographical rules that give us exact regulations for every single case. Social rules are abstractions that people use creatively. The rules do not use the people, the people use the rules (Keevallik 1998: 541). 
Keywords: cross-cultural communication, communicative approach, request strategies, politeness strategies, Estonian, Hungarian

Marju Ilves (1976) on Iõpetanud Tartu Ülikooli ungari keele ja kirjanduse alal. Kaitses magistrikraadi Tartu Ülikoolis 2005. a uurali keelte alal. Alustas doktoriõpet Pécsi Ülikooli rakenduslingvistika erialal 2003. a. Alates 2000. a eesti keele lektor Szombathelys. Uurinud sotsiaalse soo aspekti keeleõppes.

marju@fsd.bdtf.hu 